\title{
Evaluation of bread prepared from composite flour of sweet lupine and Bread wheat variety
}

\section{Biadge Kefale* and Bethel Yetenayet}

Received: 24 December, 2019

Accepted: 25 February, 2020

Published: 26 February, 2020

*Corresponding author: Biadge Kefale, Food science and Nutrition Research, Holeta Agricultural Research Center, Ethiopian Institute of Agricultural Research, Addis Ababa, Ethiopia, E-mail: biadgekefale@yahoo.com Keywords: Sweet lupine; Nutrition and sensory https://www.peertechz.com

Check for updates

Food science and Nutrition Research, Holeta Agricultural Research Center, Ethiopian Institute of

Agricultural Research, Addis Ababa, Ethiopia

\begin{abstract}
Sweet lupine is high in protein and dietary fiber. Incorporating sweet lupine flour with wheat produces more nutritious food. In the study the samples sweet lupine and wheat flour were collected from Holeta crop breeding and the bread product were made incorporating the sweet lupine (welela variety) flour with wheat flour (Dendea variety). The bread product were made with five interval from each treatment from Treatment 1 (100 wheat flour) control up to Treatment 9 (60 wheat flour: 40 sweet Lupine flour). From the bread product the nutritional and sensory data were collected. The result for the treatments Treatment 1 up to Treatment6 (75 wheat flour: 25 sweet lupine flour) had high value in protein (11.68-20.74\%) and Calcium, Zinc as well as color of bread (4.0-4.57) and taste Treatment 1-Treatment 6 (3.71-4.78). From all the treatments Treatment1- Treatment 6 had high nutritional and sensory result.
\end{abstract}

\section{Introduction}

Lupine flour was officially introduced as a food ingredient in the UK in 1996, in France in 1997, and in Australian 2001. Lupine is uniquely high in protein $(30-40 \%)$ and dietary fiber $(30 \%)$, and low in fat $(4-7 \%)$. Nutrition and medical scientists are researching the health benefits of lupine, which could potentially play a role in combating obesity and its associated health problems of diabetes and heart disease.

Yeast-raised bread is highly favored worldwide because of its desirable sensory attributes. The quality and quantity of the protein in the wheat grain has very close relationship with bread making potential. The increase in protein content can improve the baking quality as a function of qualitative nature of gluten composition. Wheat protein is deficient in some essential amino acids, especially lysine which is the first limiting amino acid in wheat [1]. This deficiency results in lowering the protein nutritional quality of products made from wheat flour [2]. The deficiency of lysine leads to the poor utilization of protein and thus results in protein malnutrition (Pellet and Ghosh).

There is great interest has been generated in supplementing wheat flour with high protein, high lysine material to increase the protein content and improve the essential amino acid balance of baked products, especially bread. The high protein and lysine content and well-balanced amino-acid composition makes cowpea an excellent source of protein with potential to enhance the protein quality (Prinyawiwatkul et al).

Incorporating up to 20 per cent lupin flour with wheat or whole meal flours produces more nutritious bread; the blend of cereal and legume helps to balance out the amino acid profile and make it a more complete food. Adding more than about five percent lupin flour into most wheat flours results in a slight loss of loaf volume, because lupin proteins lack the strength and elasticity of wheat gluten [3]. However when stronger flours, such as hard red wheat from Canada, are used it is possible to add up to 15 percent lupin flour and still retain loaf integrity and produce a quality product. The lupin wheat combination increases the water holding capacity of the product and the resultant texture, flavor and yellow colors appealing to many consumers [4]. Therefore this study was done the sweet lupine blend with wheat flour to improve protein nutrition of the society as well as to increase the utilization of newly introduced sweet lupine in Ethiopia.

\section{Material and methods}

\section{Sample collection}

The sweet lupine and Bread wheat sample was obtained 
from highland pulse breeding and wheat breeding program of Holeta Agricultural Research Center.

\section{Sample preparation}

For both sweet lupine and bread wheat the sample was graded, sorted and cleaned manually. And it is made ready by tagging each individually.

\section{Sweet lupine flour preparation}

The bean was soaked overnight $5 \mathrm{~kg}$ sample. After soaking the sample was dried in sunlight and the bean was crashed into single cotyledons. The crashed sample was milled into fine ground of $(0.5 \mathrm{~mm})$ miller sieve size.

\section{Wheat flour preparation}

The manually cleaned whole Wheat grain were milled finely by using $0.5 \mathrm{~mm}$ sieve size of sample miller and prepared for further analysis.

\section{Flour blending}

Bread wheat flour and sweet lupin flour was blended in the ratios of 95:5, 90:10, 85:15, 80:20, 75:25,70:30,65:35,60:40 and $100 \%$ wheat flour as a control with each sample weighed out into three places using a weighing balance. One hundred percent wheat flour was also weighed out into three places.

\section{Dough and Bread preparation}

The bread samples were produced in batches by mixing and kneading manually each of the above flour blends with the ingredients using a stainless-steel bowel. After thorough kneading in each case, the dough was allowed to ferment and develop for 15minutes before being knocked back and then molded into cylindrical shape. After molding in each case, the dough was then placed in a well-oiled baking pan where it proofed for 40 minutes at room temperature before it was baked in a cabinet oven pre-heated. And it was set at $2300 \mathrm{c}$ for 25 minutes.

\section{Proximate analysis}

The Association of Official Analytical Chemist (AOAC) procedure was used to determine the proximate compositions (carbohydrate, crude protein, moisture content, crude fat, total ash, dry matter) of the bread wheat, sweet lupine flour and bread samples made from the blends of the above flours.

\section{Mineral analysis}

For mineral determination, wet digestion of the all samples was carried out according to the method of (Jones et al.,). Calcium, zinc and iron was determined by atomic absorption spectrophotometer while, potassium was measured through flame photometer phosphorus content was determined using a UV-VIS spectrophotometer.

\section{Sensory analysis}

Sensory evaluation was carried out using a 20 untrained panelist in duplicate sample to assess the organoleptic attributes of the bread samples. The organoleptic attributes was assessed are; taste, aroma, texture, crumb color and the overall acceptability. The panelists were selected randomly from the staff. The panelists was instructed to rate the bread based on 5-point hedonic scale ranging from 5 =like very much to $1=$ disliked very much. The raw scores were assembled and statistically analyzed using appropriate software.

\section{Statistical analysis}

The quality characteristics of flours, as well as the baking test results of products made with sweet lupine and bread wheat flour supplementation was analyzed by one-way ANOVA (Analysis of Variance) using statistical tools of SPSS version 22.

\section{Formulation (Tables 1,2)}

Table 1: Formulations of samples from wheat (Denda variety) and sweet lupine (Welela).

\begin{tabular}{|c|c|c|}
\hline Treatments & Wheat flours in gram & Sweat lupine flour in gram \\
\hline T1 & $100 \mathrm{~g}$ & $0 \mathrm{~g}$ (Control) \\
\hline T2 & $95 \mathrm{~g}$ & $5 \mathrm{~g}$ \\
\hline T3 & $90 \mathrm{~g}$ & $10 \mathrm{~g}$ \\
\hline T4 & $85 \mathrm{~g}$ & $15 \mathrm{~g}$ \\
\hline T5 & $80 \mathrm{~g}$ & $20 \mathrm{~g}$ \\
\hline T6 & $75 \mathrm{~g}$ & $25 \mathrm{~g}$ \\
\hline T7 & $70 \mathrm{~g}$ & $30 \mathrm{~g}$ \\
\hline T8 & $65 \mathrm{~g}$ & $35 \mathrm{~g}$ \\
\hline T9 & $60 \mathrm{~g}$ & $40 \mathrm{~g}$ \\
\hline
\end{tabular}

Table 2: Ingredients for bread formulation.

\begin{tabular}{|c|c|}
\hline Ingredients & Quantity in grams \\
\hline Water & $100 \mathrm{ml}$ \\
\hline Yeast & $2 \mathrm{~g}$ \\
\hline Fat (oil) & $10 \mathrm{ml}$ \\
\hline Salt & $1 \mathrm{~g}$ \\
\hline
\end{tabular}

\section{Result and discussion}

From the flour functional property, the water absorption of the flour of wheat is greater than sweet lupine and oil absorption of sweet lupine is greater than the flour of wheat. The moisture content and ash between the treatment there is no significant different at $p<0.05$ while protein and fat between treatment were significantly different at $p<0.05$.

The sensory acceptability of the bread up to treatment T6 (75 Wheat: 25 sweet lupine) were acceptable by using fivepoint hedonic scale. Generally, by using the above functional property, nutrient content and sensory test up to T6 the sweet lupine utilization and palatability improved (Tables 3-5) (Figure 1). 
Table 3: Functional property and nutrient content.

\begin{tabular}{|c|c|c|c|c|c|c|}
\hline Flour & $\begin{array}{c}\text { Water } \\
\text { absorption }\end{array}$ & $\begin{array}{c}\text { Oil } \\
\text { absorption }\end{array}$ & $\begin{array}{c}\text { Moisture } \\
\text { content }\end{array}$ & Ash & $\begin{array}{c}\text { Protein } \\
\text { content }\end{array}$ & Fat \\
\hline $\begin{array}{c}\text { Wheat } \\
\text { (denda) }\end{array}$ & $2.7 \pm 0.30$ & $2.30 \pm 0.10$ & $9.50 \pm 0.00$ & $1.50 \pm 0.50$ & $10.66 \pm 0.40$ & $2.1 \pm 0.10$ \\
\hline $\begin{array}{c}\text { Sweat } \\
\text { lupine }\end{array}$ & $2.5 \pm 0.30$ & $3.00 \pm 0.00$ & $7.00 \pm 0.50$ & $4.20 \pm 0.25$ & $35.08 \pm 0.44$ & $7.65 \pm 0.05$ \\
\hline
\end{tabular}

Table 4: Nutrient content of formulated bread.

\begin{tabular}{|r|c|c|c|c|}
\hline Treatment & Moisture content & Ash & Protein content & Fat \\
\hline T1 & $33.6 \pm 0.00$ & $1.50 \pm 0.00$ & $12.95 \pm 0.64^{\text {cd }}$ & $6.55 \pm 0.05^{\mathrm{h}}$ \\
\hline T2 & $28.50 \pm 2.90$ & $1.50 \pm 0.00$ & $11.68 \pm 1.32^{\mathrm{d}}$ & $8.90 \pm 0.10^{\mathrm{b}}$ \\
\hline T3 & $35.40 \pm 2.20$ & $1.75 \pm 0.25$ & $14.00 \pm 2.12^{\mathrm{bcd}}$ & $8.40 \pm 0.10^{\text {cd }}$ \\
\hline T4 & $36.90 \pm 0.10$ & $1.50 \pm 0.50$ & $14.43 \pm 1.67^{\mathrm{bcd}}$ & $8.10 \pm 0.10^{\text {de }}$ \\
\hline T5 & $35.70 \pm 1.30$ & $1.75 \pm 0.25$ & $17.77 \pm 0.84^{\mathrm{abcd}}$ & $7.30 \pm 0.10^{\mathrm{g}}$ \\
\hline T6 & $36.00 \pm 1.00$ & $1.75 \pm 0.25$ & $20.74 \pm 6.89^{\mathrm{ab}}$ & $7.50 \pm 0.10^{\mathrm{fg}}$ \\
\hline T7 & $37.40 \pm 0.20$ & $2.00 \pm 0.00$ & $11.96 \pm 0.65^{\mathrm{d}}$ & $8.50 \pm 0.10^{\mathrm{c}}$ \\
\hline T8 & $35.60 \pm 2.60$ & $2.25 \pm 0.25$ & $18.87 \pm 2.29 \mathrm{a}^{\mathrm{bc}}$ & $9.35 \pm 0.15^{\mathrm{a}}$ \\
\hline T9 & $38.40 \pm 4.00$ & $2.25 \pm 0.25$ & $21.93 \pm 2.25^{\mathrm{a}}$ & $7.80 \pm 0.10^{\mathrm{ef}}$ \\
\hline
\end{tabular}

Table 5: Sensory data using five point hedonic scales.

\begin{tabular}{|c|c|c|c|c|c|c|}
\hline Treatment & Taste & color & Texture & Crumb color & Aroma & Over all \\
\hline T1 & $4.78 \pm 0.71^{\mathrm{a}}$ & $4.57 \pm 0.14^{\mathrm{a}}$ & $4.50 \pm 0.07^{\mathrm{a}}$ & $4.14 \pm 0.14^{\mathrm{a}}$ & $4.42 \pm 0.14^{\mathrm{a}}$ & $4.60 \pm 0.21^{\mathrm{a}}$ \\
\hline T2 & $4.35 \pm 0.71^{\mathrm{b}}$ & $4.07 \pm 0.07^{\mathrm{b}}$ & $4.21 \pm 0.30^{\mathrm{ab}}$ & $4.21 \pm 0.21^{\mathrm{a}}$ & $4.14 \pm 0.00^{\mathrm{b}}$ & $4.07 \pm 0.07^{\mathrm{bc}}$ \\
\hline T3 & $4.35 \pm 0.71^{\mathrm{b}}$ & $4.53 \pm 0.036^{\mathrm{a}}$ & $4.28 \pm 0.20^{\mathrm{ab}}$ & $4.35 \pm 0.07^{\mathrm{a}}$ & $3.71 \pm 0.00^{\mathrm{c}}$ & $4.42 \pm 0.00^{\mathrm{ab}}$ \\
\hline T4 & $4.21 \pm 0.71^{\mathrm{b}}$ & $4.39 \pm 0.11^{\mathrm{a}}$ & $4.21 \pm 0.30^{\mathrm{ab}}$ & $4.35 \pm 0.07^{\mathrm{a}}$ & $3.78 \pm 0.07^{\mathrm{c}}$ & $4.42 \pm 0.14^{\mathrm{ab}}$ \\
\hline T5 & $3.85 \pm 0.00^{\mathrm{c}}$ & $4.00 \pm 0.00^{\mathrm{b}}$ & $3.92 \pm 0.10^{\mathrm{b}}$ & $4.00 \pm 0.14^{\mathrm{ab}}$ & $3.78 \pm 0.07^{\mathrm{c}}$ & $3.92 \pm 0.07^{\mathrm{c}}$ \\
\hline T6 & $3.71 \pm 0.20^{\mathrm{c}}$ & $3.92 \pm 0.07^{\mathrm{bc}}$ & $3.92 \pm 0.30^{\mathrm{b}}$ & $3.57 \pm 0.14^{\mathrm{bc}}$ & $3.35 \pm 0.07^{\mathrm{d}}$ & $3.78 \pm 0.07^{\mathrm{c}}$ \\
\hline T7 & $3.21 \pm 0.71^{\mathrm{d}}$ & $3.67 \pm 0.10^{\mathrm{cd}}$ & $3.07 \pm 0.10^{\mathrm{c}}$ & $3.50 \pm 0.21^{\mathrm{cd}}$ & $3.07 \pm 0.07^{\mathrm{e}}$ & $3.00 \pm 0.14^{\mathrm{d}}$ \\
\hline T8 & $2.92 \pm 0.71^{\mathrm{e}}$ & $3.50 \pm 0.00^{\mathrm{de}}$ & $2.92 \pm 0.10^{\mathrm{c}}$ & $3.07 \pm 0.07^{\mathrm{d}}$ & $2.71 \pm 0.00^{\mathrm{f}}$ & $3.00 \pm 0.00^{\mathrm{d}}$ \\
\hline T9 & $2.71 \pm 0.00^{\mathrm{e}}$ & $3.39 \pm 0.035^{\mathrm{e}}$ & $2.78 \pm 0.10^{\mathrm{c}}$ & $3.14 \pm 0.14^{\text {cd }}$ & $2.64 \pm 0.07^{\mathrm{f}}$ & $2.85 \pm 0.14^{\mathrm{d}}$ \\
\hline
\end{tabular}

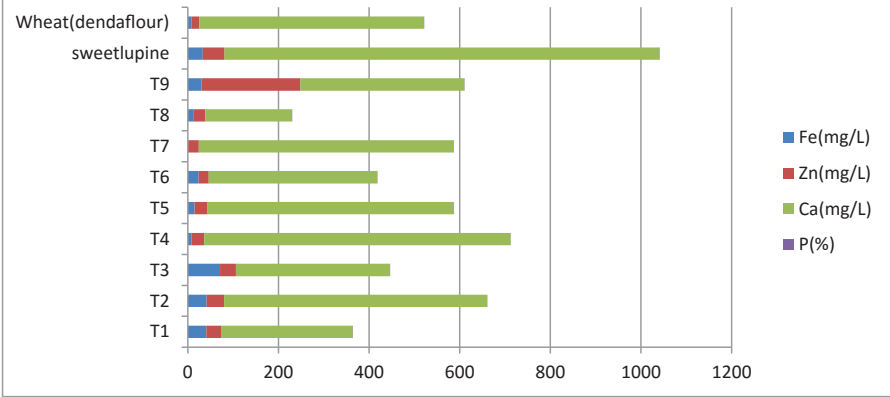

Figure 1: Mineral content of Formulated Bread.

\section{Nutrient content of wheat and sweet lupine flour and their blend}

From the flour functional property, the water absorption of the flour of wheat is greater than sweet lupine and oil absorption of sweet lupine is greater than the flour of wheat. The moisture content and ash between the treatment there is no significant different at $p<0.05$ while protein and fat between treatment were significantly different at $p<0.05$. Lupine is a good source of nutrients, not only proteins but also lipids, dietary fibre, minerals, and vitamins [5]. Lupine flour showed higher level of oil absorption, protein content, fat content and ash content than wheat flour conversely wheat flour showed higher level of water absorption and moisture content.

This result confirmed by statically analysis which highly significant difference $(p<0.05)$ where obserebed between the two type of flours. Mean ash content and protein content increased with increasing amount flour to be substituted with wheat flour with lupine flour at 5, 10, 15 respectively on dry weight basis. There was no significant difference between wheat flour and supplemented flour with different concentration of lupine flour moisture and ash content of the blend. The chemical properties of wheat flours have been studied previously by several researchers and they found that moisture content ranged between 12.5 to $14.6 \%$ crude protein content 8.23 to $12.71 \%$ and ash content 0.42 to 0.66 [6].

Protein content of lupine $(38.6 \%)$ was higher than that of a lot of legumes. Favier et al. [7], reported that haricot bean, lentil and soy bean contain $28.8 \%, 26.7 \%$ and $40.5 \%$ protein, respectively. Because of the high protein content, lupine flour could be used in the human diet. Also, temperature of denaturation of these proteins is higher than animal protein, so they are technologically easier to handle [8].

\section{Mineral content of wheat and sweet lupine flour and blend}

The mineral content of wheat flour and sweet lupine flour especially the calcium content of sweet lupine higher compared to wheat flour as well as the concentration of sweet lupine flour increase the calcium content of the blend. Treatment 9 (wheat 60: Sweet lupine 40) were higher zinc concentration compared to other treatments. While wheat flour and sweet lupine flour zinc concentration had higher for sweet lupine concentration (47.96) compared to wheat flour (17.04). Lupin flour higher amounts of $\mathrm{Ca}, \mathrm{Zn}, \mathrm{k}$, and $\mathrm{P}$ when compared to wheat flour. Similar results for mineral content of lupin flour have been reported in previous works [9-14].

\section{Sensory evaluation of the blend}

The sensory acceptability of the bread up to treatment T6 (75 Wheat: 25 sweet lupine) were acceptable by using fivepoint hedonic scale. Bread containing lupine flour up to $30 \%$ substitution level gave higher or similar sensory score in terms of all sensory property compared to control bread [15]. Reported that $10 \%$ addition level of lupine flour or hull to shortcakes, ginger breads, pancakes enables preparation good quality food stuffs in terms of sensory properties.

\section{Conclusion}

Generally, by using the above functional property, nutrient content and sensory test up to Treatment 6 (75 Wheat: 25 sweet lupine) the sweet lupine utilization and palatability were improved. Lupine is a good source of nutrients not only proteins but also lipids, dietary fiber, minerals and vitamins while the concentration of lupine increase in the flour proportion of wheat the concentration of protein of the bread product were 
increased. The mineral content of lupine flour and the mixture were higher for the concentration of calcium and zinc content as well as the color of the bread in the sensory observation was higher recorded. From this the bread product formulations have good result in industrial processing for bread production and to combat protein and micronutrient (zinc) malnutrition. Bread producers in Ethiopia up to $25 \%$ sweet lupine substitution of wheat can use to improve the society nutritional status and to produce good quality bread.

\section{References}

1. Kent NL, Evers AD (1994) Technology of Cereals. $4^{\text {th }} /$ Ed. Pergamon Press, Oxford 352. Link: http://bit.ly/2TOuhSc

2. Wrigley CW, Bietz JA (1988) Proteins and amino acids. In Wheat: Chemistry and Technology. 1: 159-275.

3. Lucisano M, Pompei C (1981) Baking properties of lupin flour. Food Science 14: 323-336. Link: http://bit.ly/2Vu6hZn

4. Petterson DS, Crosbie GB (1990) Potential for lupins as food for humans. Food Australia 42: 266-268. Link: http://bit.ly/3ablnpD

5. Martínez-Villaluenga $\mathrm{C}$, Zieliński H, Frias J, Piskuła MK, Kozłowska H, VidalValverde C (2009) Antioxidant capacity and polyphenolic content of highprotein lupin products. Food Chemistry 112: 84-88. Link: http://bit.ly/2Vp3r7U

6. Ahmad I, Anjum FM, Butt MS (2001) Quality characteristics of wheat varieties grown in Pakistan from 1933-1996. Pak J Food Sci 11: 1-4. Link: http://bit.ly/2Teba64

7. Favier JC, Ripert JI, Toque C, Feinberg M (1995) Répertoire général des aliments: Table de composition = Composition tables. 927. Link: http://bit.ly/2HURpuK
8. Chapleau N, de Lamballerie-Anton M (2003) Improvement of emulsifying properties of lupin proteins by high pressure induced aggregation. Food Hydrocolloids 17: 273-280. Link: http://bit.ly/2PqtgRf

9. Trugo LC, Donangelo CM, Duarte YA, Tavares CL (1993) Phytic acid and selected mineral composition of seed from wild species and cultivated varieties of lupin. Food Chem 47: 391-394. Link: http://bit.ly/2v8pTHL

10. Dervas G, Doxastakis G, Hadjisavva-Zinoviadi S, Triantafillakos N (1999) Lupin flour addition to wheat flour dough and effect on rheological properties. Food Chem 66: 67-73. Link: http://bit.ly/32zFT1G

11. Doxastakis G, Zafiriadis I, Irakli M, Marlani H, Tananaki C (2002) Lupin, soya and triticale addition to wheat flour doughs and their effect on rheological properties. Food Chem 77: 219-227. Link: http://bit.ly/38ZKz33

12. Lampart-Szczapa E, Siger A, Trojanowska K, Nogala-Kalucka M, Malecka $M$ et al. (2003) Chemical composition and antibacterial activities of lupin seeds extracts. Nahrung 47: 286-290. Link: http://bit.ly/2TOuFjC

13. Martínez-Villaluenga C, Sironi E, Vidal-Valverde C, Duranti M (2006) Effects of oligosaccharide removing procedure on the protein profiles of lupin seeds. Eur Food Res Technol 223: 691-696. Link: http://bit.ly/2HTESI8

14. Yorgancýlar M, Atalay E, Babaoglu M (2009) Acýlýðý giderilmip termiye tohumlarýnýn (lüpen= lupinus albus I.)mineral içerigi. Selçuk Tarim ve Gida Bilimleri Dergisi 23: 10-15. Link: http://bit.ly/2vkPg9d

15. Gorecka D, Lambart Szcapa E, Janitz W, Sokolowska B (2000) Composition of fractional and functional properties of dietary fiber of lupines (L. luteus and $L$. albus), Nahrung Foods 44: 229-232. Link: http://bit.ly/2Vn1A3l

16. AACC (1990) Approved Methods of the American Association of Cerea Chemists. American Association of Cereal Chemists, Inc; St Paul, Minnesota, USA.

17. Alamanou S, Bloukas JG, Paneras ED, Doxastakis G (2002) Influences of protein isolate from lupin seeds (Lupinus albus ssp. Graecus) on processing and quality characteristics of frankfurters. Meat Sci 42: 79-93.
Discover a bigger Impact and Visibility of your article publication with Peertechz Publications

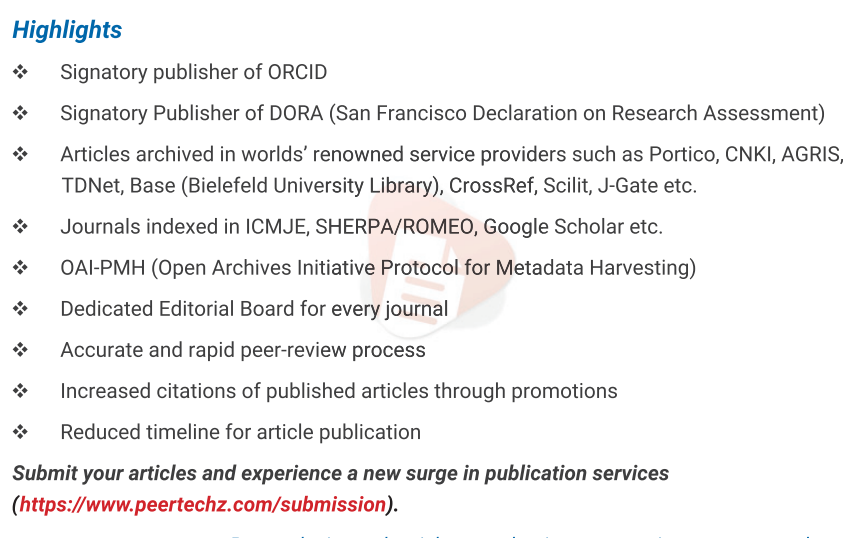

Peertechz journals wishes everlasting success in your every endeavours.

Copyright: @ 2020 Kefale B, et al. This is an open-access article distributed under the terms of the Creative Commons Attribution License, which permits unrestricted use distribution, and reproduction in any medium, provided the original author and source are credited. 